\title{
THE DYNAMICS OF MICROLYMPHATIC FLOW IN TWO-STAGE SURGICAL TREATMENT OF PILONIDAL ABSCESS AND THE USE OF REGIONAL LYMPHATIC
} AND NO-THERAPY

\author{
Article history: \\ Received 25 February 2019 \\ Received in revised form 27 March 2019 \\ Accepted 4 April 2019
}

\section{M.A. Topchiev, V.V. Melnikov, D, S. Parshin, Sh.M. Tarikuliev}

\author{
Astrakhan State Medical University of the Ministry of Healthcare of the \\ Russian Federation, Astrakhan, Russia
}

\begin{abstract}
Comparative results of non-invasive laser Doppler flowmetry of micro-blood-flow and micro lymphatic flow in the tissues adjacent to the wound with two-stage surgical treatment of 29 patients with pilonidal abscesses are given. In the studied group of patients (15), regional lymphatic therapy (RLT) and NO-therapy were performed. In the comparison group (14), comparable by sex and age, the treatment was carried out by the traditional administration of similar antibiotics, immunomodulator and UHF-therapy. It was revealed that in the studied group, the micro-blood-flow and lymphatic flow normalized almost 2 days earlier due to regional lymphotropic antibiotic, immune and NO-therapy.
\end{abstract}

KEYW ORDS - piloid abscess, micro lymphatic flow, lymphatic and NO-therapy.

\section{INTRODUCTION}

Restoration of hemodynamics in the microvasculature and lymphatic flow in the wound walls and adjacent tissues depend on the effectiveness of the drug therapy aimed at suppressing the activity of wound microflora and stimulating local immune protection $[1,2]$.

Thanks to the creation of the LAKK device cluster (NPP "Lazma”, Russia), in particular "LAZMA $M C$ ", it became possible to conduct laser Doppler flowmetry and explore the state of the microhemolimphcirculation $[3,4,5]$. Information on laser Doppler flowmetry in the application of regional lymphotropic antibiotic, immune and NO-therapy in the complex treatment of piloidal abscesses is absent in both domestic and foreign scientific literature.

\section{MATERIALS AND METHODS}

Micro-blood-flow and micro lymphatic flow were studied in 15 male patients (mean age $22 \pm 1.4 \mathrm{~g}$ ) treated with regional lymphotropic administration of cefotaxime 1.0, diluted in $4 \mathrm{ml}$ of a $0.5 \%$ lidocaine solution +32 units of Lydazum and Imunofan $(50 \mathrm{mg}$, diluted in $4 \mathrm{ml}$ of $0.9 \%$ sodium chloride solution) at 48 hour intervals. Every day, with a 5-minute exposure, the wound and the adjacent tissues were treated with a stream of exogenous nitric oxide (ENO) produced by the Plason device in the stimulator mode from a distance of $25 \mathrm{~cm}$ from the nozzle. In the comparison group (14 men), comparable by sex and age, the treatment was carried out by traditional administration of similar drugs and UHF-therapy. Installation of sensors for information retrieval was carried out in $1 \mathrm{~cm}$ from the upper angle, to the right and left of the postoperative wound in the middle part of it at different times: after the operation, after days 1,3 and 6 from the start of treatment. Information retrieval was carried out in the supine position, at a room temperature of $25^{\circ} \mathrm{C}$. Reference values were obtained from 9 healthy males aged 20 to 22 years. We studied M - the average flow in the microcirculatory bed, Q - an indicator affecting the constancy of particles in the lymphatic bed and $\mathrm{L}$ - coefficient of red blood cell dispersion in the probed tissue volume. Reference values of these indicators were obtained from 9 healthy males aged 20 to 22 years. The research results were compared with the clinical course of the wound process and were analyzed by methods of variation statistics using the Statistica 6.0 program. The research results are presented in the table 1.

In the comparison group, the indicators $\mathrm{M}, \mathrm{Q}$, Kv before the surgery scarcely differed from those $(\mathrm{p}<0.05)$ of the main group and on the day 3 of postoperative treatment only approached the results obtained on the $6^{\text {th }}$ day of treatment in the main group. Thus, the application of the developed algorithm for the complex treatment of piloidal abscesses has a pathogenetically substantiated effect on the course of the wound process. RLT in combination with the processing of paravulnar tissues by the ENO stream produced by the "Plason" device in the "stimulator" mode, contributes to its earlier transition to the regeneration phase.

Thus, the application of the developed algorithm for the complex treatment of pilonidal abscesses has a 
Table 1. Dynamics of indicators of the results of laser Doppler flowmetry of the micro-lymphocytic circulatory bed of postoperative wounds of the piloidal area in the studied group of patients $(n-15)$

\begin{tabular}{|c|c|c|c|c|c|c|}
\hline & Wound area & Reference indicators & After surgery & Day 1 & Day 3 & Day 6 \\
\hline & \multicolumn{6}{|c|}{ Microcirculation indicators } \\
\hline 离递 & $\begin{array}{l}M \\
0 \\
K v\end{array}$ & $\begin{array}{l}6,71 \pm 1,23 \\
0,67 \pm 0,09 \\
9,64 \pm 2,1\end{array}$ & $\begin{array}{l}3,76 \pm 1,28 \\
3,67 \pm 0,19 \\
49,62 \pm 4,1\end{array}$ & $\begin{array}{l}6,71 \pm 1,23^{*} \\
2,67 \pm 0,09^{*} \\
39,64 \pm 2,1^{*}\end{array}$ & $\begin{array}{l}9,76 \pm 1,22^{* *} \\
1,61 \pm 0,09^{*} \\
19,64 \pm 2,10^{*}\end{array}$ & $\begin{array}{l}12,61 \pm 1,28 \\
0,87 \pm 0,09 \\
12,64 \pm 2,1\end{array}$ \\
\hline 흥 & $\begin{array}{l}M \\
0 \\
K v\end{array}$ & $\begin{array}{l}8,7 \pm 1,25 \\
0,69 \pm 0,10 \\
9,84 \pm 2,6\end{array}$ & $\begin{array}{l}3,76 \pm 1,28 \\
4,61 \pm 0,17 \\
48,72 \pm 3,6\end{array}$ & $\begin{array}{l}10,56 \pm 1,20^{*} \\
3,68 \pm 0,19^{*} \\
39,62 \pm 4,0^{*}\end{array}$ & $\begin{array}{l}9,56 \pm 1,20^{*} \\
1,58 \pm 0,19^{*} \\
19,62 \pm 3,1^{*}\end{array}$ & $\begin{array}{l}9,10 \pm 1,25^{*} \\
1,08 \pm 0,16^{*} \\
12,60 \pm 3,12^{*}\end{array}$ \\
\hline 㝳 & $\begin{array}{l}\mathrm{M} \\
0 \\
\mathrm{Kv}\end{array}$ & $\begin{array}{l}9,1 \pm 2,0 \\
0,72 \pm 0,11 \\
9,95 \pm 2,5 \\
\end{array}$ & \begin{tabular}{|l|}
$4,76 \pm 1,20$ \\
$2,70 \pm 0,18$ \\
$48,62 \pm 4,22$ \\
\end{tabular} & $\begin{array}{l}11,56 \pm 1,20^{*} \\
2,17 \pm 0,15^{*} \\
38,62 \pm 4,11^{*}\end{array}$ & $\begin{array}{l}10,56 \pm 1,20^{*} \\
2,01 \pm 0,15^{*} \\
18,52 \pm 4,11^{*}\end{array}$ & $\begin{array}{l}10,01 \pm 1,20^{* *} \\
1,17 \pm 0,15^{*} \\
12,60 \pm 4,10^{*}\end{array}$ \\
\hline & \multicolumn{6}{|c|}{ Lymph flow Indicators } \\
\hline 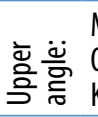 & $\begin{array}{l}M \\
0 \\
K v\end{array}$ & $\begin{array}{l}0,57 \pm 0,09 \\
0,71 \pm 0,10 \\
10,12 \pm 2,7\end{array}$ & $\begin{array}{l}3,76 \pm 0,28 \\
3,67 \pm 0,19 \\
49,62 \pm 4,1\end{array}$ & $\begin{array}{l}1,71 \pm 0,23^{*} \\
1,97 \pm 0,09^{*} \\
39,64 \pm 2,1^{*}\end{array}$ & $\begin{array}{l}1,06 \pm 0,20^{* *} \\
1,28 \pm 0,18^{*} \\
29,64 \pm 2,10^{*}\end{array}$ & $\begin{array}{l}1,00 \pm 0,28^{* *} \\
0,87 \pm 0,09^{* *} \\
12,64 \pm 2,1^{* *}\end{array}$ \\
\hline 흘홍 & $\begin{array}{l}M \\
0 \\
K v\end{array}$ & $\begin{array}{l}0,78 \pm 0.12 \\
0,79 \pm 0,02 \\
19,84 \pm 3,54\end{array}$ & $\begin{array}{l}0,16 \pm 1,28 \\
3,64 \pm 0,18 \\
49,62 \pm 4,1\end{array}$ & $\begin{array}{l}1,66 \pm 1,20^{*} \\
1,98 \pm 0,08^{*} \\
39,60 \pm 4,3^{*}\end{array}$ & $\begin{array}{l}1,06 \pm 1,20^{*} \\
1,28 \pm 0,19^{*} \\
29,62 \pm 3,1^{*}\end{array}$ & $\begin{array}{l}0,9 \pm 0,15^{* *} \\
1,08 \pm 0,16^{* *} \\
19,60 \pm 3,12^{* *}\end{array}$ \\
\hline 형 & $\begin{array}{l}\mathrm{M} \\
0 \\
\mathrm{Kv}\end{array}$ & $\begin{array}{l}0,80 \pm 0,09 \\
0,80 \pm 0,08 \\
20,01 \pm 2,96\end{array}$ & $\begin{array}{l}4,76 \pm 1,20 \\
2,70 \pm 0,18 \\
48,62 \pm 4,22\end{array}$ & $\begin{array}{l}11,80 \pm 1,21^{*} \\
2,09 \pm 0,15^{*} \\
38,60 \pm 4,11^{*}\end{array}$ & $\begin{array}{l}10,56 \pm 1,20^{*} \\
2,07 \pm 0,15^{*} \\
28,62 \pm 4,11^{*}\end{array}$ & $\begin{array}{l}10,01 \pm 1,20^{* *} \\
1,17 \pm 0,15^{* *} \\
19,60 \pm 4,10^{* *}\end{array}$ \\
\hline
\end{tabular}

${ }^{*} p<0,05$ from the start of treatment; ${ }^{* *} p<0,01$ from the start of treatment

pathogenetically substantiated effect on the components of the course of the wound process. RLT in combination with the processing of paravulnar tissues with the ENO stream produced by the "Plason" device in the "stimulator" mode contributes to earlier stopping of the inflammation phase of the wound process.

The dynamics of the result indicators of laser Doppler flowmetry of the micro-blood-flow and lymphatic flow in the study group confirm a more rapid normalization of the micro-blood-flow in the paravulnar tissues and the lymphatic-stimulating effect of regional antibiotic, immuno-and NO-therapy, which ultimately improves the quality of complex treatment of abscesses in the pilonidal area.

\section{REFERENCES}

1. Melnikov V.V., Zhurbina G.V., Parshin D.S. Lymphatic therapy in the complex treatment of postinjection complications in patients with parenteral addiction. Surgeon. 2016;2:12-17.(In Russ).

2. Topchiev M.A., Melnikov V.V., Parshin D.S., TARIKUliev M.SH. Regional antibiotic, immune and $\mathrm{NO}$ - therapy in the complex treatment of the pilonidal cyst at the stage of abscess formation. Kuban Scientific Medical Bulletin. 2017;1(162):139-141.(In Russ).

3. Krupatkin A.I., Sidorov V.V. New opportunities for non-invasive evaluation of micro- lymphatic flow using laser technology. Bulletin of lymphology. 2014;4:21-28.(In Russ).
4. Demin V.V., Kozlov I.O., Zherebtsov E.I. Possibilities of laser Doppler flowmetry in assessing the state of microhemolymphatic circulation. Regional blood supply and microcirculation. 2017;16(4):42-49. DOI: 10.24884/1682-6655-2017-16-4-42-49.

5. Safonova T.N., Kityukhina N.P., Sidorov V.V. Study of microcirculation of the blood flow and lymph flow in the eyelid skin using laser Doppler flowmetry. Bulletin of Ophthalmology. 2017;3:16-21 .(In Russ). 